\title{
WAYS TO EXPLICATE COURTESY PRINCIPLES IN THE CHUVASH, MARI, RUSSIAN AND FRENCH LANGUAGES
}

\author{
Galina G. Yakovleva ${ }^{1}$, Alena M. Ivanova ${ }^{2}$, Tatyana A. Soldatkina ${ }^{3 \star}$, Oleg N. Viktorov ${ }^{4}$ \\ ${ }^{1}$ Prof. Dr., I. N. Ulyanov Chuvash State University, RUSSIA, yakovlevagalinagr@mail.ru \\ ${ }^{2}$ Prof., Dr., I. N. Ulyanov Chuvash State University, RUSSIA, amivano@rambler.ru \\ ${ }^{3}$ Assoc. Prof., Mari State University, RUSSIA, fia.solta@gmail.com \\ ${ }^{4}$ Assoc. Prof., I. N. Ulyanov Chuvash State University, RUSSIA, viktorovon@mail.ru \\ ${ }^{*}$ Corresponding Author
}

\begin{abstract}
This research is carried out in the framework of such related sciences as cultural linguistics, pragmatics, comparative linguistics, and discourse studies. The increasing role of communication, as well as the dialogue of cultures contribute to the relevance of the work. Speech interaction is a universal means regulates the courtesy. It expresses good manners and awareness of etiquette as well as it manifests sincere benevolence towards people. The authors of this article consider different approaches to the study of the courtesy category. The courtesy is defined as a pragmalinguistic category represented in different linguistic cultures. Courtesy markers in different structural languages, namely in Chuvash, Mari, Russian and French, have been defined in the article. The courtesy principles and their verbal means of expression at the lexical and grammatical levels have been analyzed. The examples of interrogative and narrative constructions as courtesy markers typical of these linguistic cultures' representatives have been considered. Ethnocultural courtesy markers characteristic of a particular linguistic culture have been revealed when analyzing the dialogical texts on the material of the Chuvash, Mari, Russian and French languages. Linguistic means of courtesy explication have been compared. The frequency of their usage in these languages has been stated. The authors stress that four cultures under consideration treat courtesy as respect for other participants in communication. Communicants express respect for each other through speech units. There is a great deal of lexical and grammatical means for courtesy principles explication in dialogical texts of modern Chuvash, Mari, Russian and French authors under analysis.
\end{abstract}

Keywords: cultural linguistics, universal, speech interaction, courtesy principle, communication.

\section{INTRODUCTION}

In the modern world, communication covers all aspects of a person's life. It represents a multifaceted process of interaction between interlocutors, the transfer of information with the communicants' specific purpose of influencing each other and their choice of communicative intentions.

Any communication is a dialogue interaction which is realized in certain sociocultural communication situations. Success and effectiveness in communication depend on knowledge of the following categories: logics, psychology, and speech. The degree of effectiveness in verbal communication is determined by the results of the implementation of two communicatively significant functions. They are interaction and impact. The major purpose of any type of communication is to achieve mutual understanding, acceptance and implementation of speech.

The courtesy principle is an important regulator of the communicants' behavior in the process of speech interaction. Being a sociocultural component of communication reflected in a language, courtesy is a pragmalinguistic category based on extralinguistic rules of politeness and on the functional semantic field of 
language units expressing politeness.

The problem of communicants' polite verbal behavior has attracted the attention of linguists, psychologists, historians and educators for millennia. Nevertheless, some issues still remain unsolved in case they are related to the implementation of this principle in various linguistic cultures or the courtesy explication in discourse as strategic means to achieve the specific purpose of partners' interaction if they speak different languages.

The object of our study is courtesy as a pragmalinguistic category, presented in the Chuvash, Mari, Russian and French languages.

The subject of the research is verbal means of courtesy principles explication in the Chuvash, Mari, Russian and French languages.

The scientific novelty of the study lies in the fact that the means of courtesy principles implementation in different structural languages have been examined for the first time. They were systematized at the lexical, morphological and syntactic levels. Universal and ethnocultural courtesy markers in the Chuvash, Mari, Russian and French languages were examined for the first time.

\section{METHODOLOGY}

The material for the report has been provided through the examples with courtesy markers extracted by continuous sampling method from the works of the Chuvash, Mari, Russian and French writers.

The study is also based on speech formulas of courtesy principles selected by the method of partial selection from various lexicographic works such as, for example, the famous Dictionary of the Chuvash language by N. I. Ashmarin, published in 17 volumes (Ashmarin, 1994-2000), the Chuvash-Russian Dictionary (Andreev, 1985), Dictionary of the Mari Language (Dictionary, 1990-2005), the Explanatory Dictionary of the Russian Language edited by D. N. Ushakov (Ushakov, 1935 ), the widely used Explanatory Dictionary of the Russian language by S. I. Ozhegov (Ozhegov, 1996), as well as The New French-Russian Dictionary by V. G. Gak (Gak, 2003).

To reach this goal, the methods of contextual and functional analysis, the method of semantic and pragmatic interpretation, as well as linguistic, cultural, comparative and lexicographic methods have been used.

The theoretical basis of the study were the works of the Russian and foreign scientists in the field of semiotics, linguistic culture, ethno-sociolinguistics, comparative grammar, pragmatics and discourse study (N. I. Ashmarin, N. I. Formanovskaya, V. G. Gak, G. Leach and others).

\section{RESULTS}

\subsection{Different Approaches to Courtesy Definition}

Recently, linguistic science has shown a growing interest in studying communication problems, namely, the structure and special characteristics of the speech situation, tactics and communication strategies of communicants, the effectiveness and results of the partners' speech interaction. The courtesy principle plays an important role regulating the linguistic communication process. The courtesy principles as a postulate of communication, the rule of verbal behavior are quite well-known from Geoffrey Leech's works. In his opinion, politeness is strategic conflict prevention and respect for others (Leech, 2014). The implementation of the courtesy principle requires compliance with a number of regulations: generosity, tact, restraint, approval, modesty, sympathy, agreement. Courtesy is usually understood as the ability to communicate respectfully and tactfully with each other, the willingness to find a compromise and listen to the point of view of the interlocutor. Politeness is considered as an expression of good manners and etiquette awareness. It allows people to feel comfortable in communication and avoid tension in relationships.

According to N. I. Formanovskaya, courtesy is a manifestation of respect for the addressee. It is a sociocultural component of communication which is associated with speech. It is a moral quality that characterizes human behavior (Formanovskaya, 1989).

In our study, courtesy is considered as a pragmalinguistic category, which is realized in speech interaction with a certain set of verbal means whose main purpose is to achieve a communicative effect.

Compliance with the courtesy principle is an important linguistic and social characteristic of the communicants' speech behavior, which represent certain ethno-cultural community. Thus, the polite relations of the Chuvash, Mari, Russian and French to their interlocutors have been repeatedly noted in the studies by historians, linguists and journalists. For example, the famous enlightener of the Chuvash people I. Ya. Yakovlev writes in his memoirs that 'there is a lot of lovely in the character of the Chuvash people. They 
have some special delicacy in mutual relations that came to them from God knows where and how. The Chuvash people avoid telling someone rude words, anything offensive, humiliating, insulting' (Yakovlev, 1985). Courtesy is defined in the Chuvash language as 'евӗклӗх, сӑпайлӑх, с̧епӗс̧лӗх', that means politeness, tact, ability to communicate with people respectfully and tactfully (Andreev, 1985, p. 712).

Among the Mari people, a polite person is considered to be 'correct, amiable, courteous, helpful, respectful, kind' (The Dictionary of the Mari Language, 1990-2005).

In the Russian tradition, courtesy is a moral quality of a person associated with his speech behavior and aimed at harmonization of relationships. Courtesy is politeness, good manners, observance of decency rules (Ushakov, 1935).

Politeness for the Chuvash, Mari and Russian is also honour, respect for elders.

Politeness also occupies an important place in the life of the French. A majority of the French consider politeness to be the most important human quality. For them, politeness is a set of rules used to direct customs in society, as well as the manner to observe these customs by an individual representative of society (Le Grand Robert, 1990). Such qualities as gallantry, courtesy, and the ability to live in a team are characteristic features of the French.

The study of linguistic literature and the analysis of lexicographic works show that courtesy is characteristic of representatives of all four linguistic cultures which were considered. The rules and principles of courtesy are used in any situation of speech interaction in the Chuvash, Mari, Russian and French languages. Each language has a wide range of linguistic means for expressing the courtesy principles. The verbal means that express this category have been considered to define frequency of their use in the discourse of the speakers who belong to these linguistic cultures.

\subsection{Varieties of Courtesy Markers in Dialogical Communication}

Speech statements are often accompanied by polite formulas in speech interaction. Thus, with the help of the lexemes тархасшӑн 'please', ыйтатӑп 'I ask; I ask you; I beg you', йăлӑнатӑп 'I beg' in the Chuvash language; поро лий, поро лийза 'be so kind', сӧрвалем йодам 'I plead you' in the Mari language; позвольте 'let me', будьте добры 'be so kind', прошу тебя (Bac) 'I ask you', умоляю тебя (Bac) 'I plead you' in the Russian language; je vous prie, je te prie, je te (vous) supplie, s'il vous (te) plait are used in French. For example:

Chuvash: Вула, тархасшӑн 'Read it, please'. Тархасшӑн, кас̧арӑр. 'Please, forgive me'. Тархасшӑн, ămă cĕm 'Here you are, your warm milk'.

Mari: Палыдыме публикым ончалаш йодам. 'I ask the public to pay attention'; Поро лийза, книгам портылташ ида мондо. 'Don't forget to return the book, if you please'.

Russian: Садитесь - прошу. 'Sit down, please'. Не смей - я тебя умоляю. 'Oh, no, don't do that, I tell you'. Давайте, пожалуйста, работать. 'Let's stick to business, please';

French: Dis je t'en prie. Je vous en prie, ne cherchez pas! Dites-moi vite! Je vous en supplie! Passez moi s'il vous (te) plaît.

These examples show that polite formulas and their synonyms are universal markers of politeness in these languages and they are present in various statements of request, invitation, apology.

Observation of communicants' verbal behavior who are the representatives of the linguistic cultures under consideration shows that the lexical unit 'please' (in the Chuvash language - тархасшӑн, in Mari - поро лий, поро лийза, in Russian - пожалуйста, in French - s'il vous (te) plaît) is used more frequently in communication. As a rule, polite formulas are combined most of all with imperative verb phrases.

Imperative forms of verbs with affixes -сам, -сем, -самӑр, -семӗр are widespread in the Chuvash language as a means of expressing politeness. They are exclusively characteristic of this language and they have been specified as ethnically specific markers of politeness.

For example: Кил, ларсам юнашар хам суума. 'Come here, please, sit next to me' in the Chuvash language. Максим Иванович, Виктор Ильич, тепрер стакан ес̧семӗр. 'Maxim Ivanovich, Victor llyich, please drink one more glass'.

The affix -ччe is often added to these forms of the imperative to put it mildly in the Chuvash language: Chuv. Ӑсатсамччӗ, Йӑкӑнат 'Please, take him to the door, Ignat', Ирӗк парсамӑрччӗ пӗр-ик сӑмах калама. 'Please, let me put my word for it?' 
In the Mari language, the speaker politely transmits the request using special markers: imperative with word пожалуйста 'please': Кондо пӧкеным, пожалуйста. 'Bring me the chair, please'. Поро лийза, каласыза ик-кок шомакым. 'Be so kind to say some words?'

It should be noted that the imperative constructions which contain such polite formulas as 'please', 'be kind', 'be nice' are the functional analogue of the above statements in the Russian language. For example: Подпишитесь, пожалуйста! 'Could you sign it, please?' Будьте добры, напишите Ваш aдрес. 'Would you write your address, please?'

In French, the most commonly used interrogative polite formulas are: Ne pourriez-vous dire votre adresse? 'Will you give your address?' Such politeness markers as S'il vous (te) plait (for example: Entre, s'il te plaît) are used in the neutral sphere of communication as well as the speech formulas Je t'en supplie (for example: Ecoute, je t'en supplie).

It is important to mention that the use of these constructions in speech interaction is regulated by the etiquette which is specific to this culture. Thus, in dealings with older people or people who have high social status, the form of the second person plural is used instead of the second person singular as a sign of respect and tact. For example, in the Chuvash language: Чӑматанӑра йӑтма ирӗк парсамӑрчче̌. 'Please, allow me to lift your suitcase'. The same pattern is observed in the conversation of seniors with juniors as a sign of sympathy, for example: С̧амрӑк тусӑм, килсемӗр кунта. Кӗрӗр. 'Young friend, please come here. Come in'.

Similarly in the Mari language, as well as in the Russian language:

Mari: Вуеш ида нал, Демьян Тихонович, чай йуашда жап. 'I am Sorry, Demyan Tikhonovich, it is time to drink tea'; Поро лийза, Миклай кугызай, эртыза эртыза, ида вожыл. Miklay, will you come in, please, don't be shy'.

Russian: Николай Петрович, проводите, пожалуйста! 'Nikolay Petrovich, will you accompany him, please?' Друзья, присоединяйтесь к нам! 'Dear friends, feel free to join us, please'.

Modal interrogative constructions are used in such situations in the French language, for example: Madame, voulez-vous me donner un sou pour payer une messe qui la sauvera. Madame, pourriez-vous me dire s'il est vrai que le pape fait faire ses robes cher Woith.

In addition to the above imperative constructions, native speakers of the Chuvash, Mari, Russian and French languages widely use imperative forms of verbs with interjections and particles, which help to make the utterance milder. They are typical for lively conversational speech. For example,

In the Chuvash language: Сапри, вула-ха. 'Sapri, read it'. Атя, кӗрсе калас̧ар. 'Ayda, let's go for conversation';

In the Mari language: Айда куштена. 'Let's dance'; Айста мемнан деке пурена. 'Let's go to us'; Миклай, луд-я. 'Miklay, you read it, will you?'

In the Russian language: Коля, прочти-ка. 'Kolya, read it, will you?' Давай, проходи. 'Common, come in'.

S'il te plait is used instead of particle -ка in the French language: Jean, lis, s'il te plaît! Allez, montez làdedans.

It should be noted that these imperative constructions are implemented in a variety of combinations in the speech interaction and they are differentiated by degrees of politeness. For example, politeness may be graded by means of repetitions.

In particular, in the Chuvash language:

Ан кай-ха, кӑштах тӑхтасам. 'Don't leave, please, wait'. (Courtesy markers are repeated in this example: particles -ха and affix -сам); Йӑӑкӑм, лӑплансам, лӑплансамчче̌. 'Sister, calm down, please, calm down, please'. (The repetition of the verb and affix -сам in the same statement).

In the Mari language: Сӧрвален йодам кевытыш миен толаш. 'I ask you to go to the shop.' (There are repetitions of courtesy markers which are special words йодам, сӧрвалем). Йодам тыйым, сорвален йодам тыйым, коден ит кай мыйым. 'I plead you not to leave me alone.' (The lexemes beg, plead are used as courtesy markers).

In the Russian language: Прошу Вас, умоляю, не преследуйте меня. (There are repetitions of courtesy markers which are special words прошу 'I ask you', умоляю 'I plead you' in the given example). Сынок, успокойся, пожалуйста, успокойся же. 'My son, calm down, calm down at last'. (The use of courtesy 
markers: the special word пожалуйста and the particle же in combination with the recurring verb успокойся).

In the French language: Je t'en prie, ne dis pas; je t'en supplie (repetition of special polite words je t'en prie, je t'en supplie). Je vous en supplie, je vous en supplie ... oubliez vite, monsieur, votre fils (the repetition of expression: je vous en supplie).

The scale of politeness is very diverse in these examples. There are both an increase and a decrease in the politeness degree in these statements, gradation is used by the speaker in speech interaction to enhance or soften the effect on his partner.

In some cases, more than two or three courtesy markers can be used within a single statement, for example:

In the Chuvash language: Закир, ырӑ пулсам, тархасшӑн, часрах лаша кӱлсе килсемччӗ. 'Zakir, please be so kind, harness the horse, please' (four markers are used in this sentence);

In the Mari language: Мый тыйым сӧрвалем, айда, пожалуйста, акайлан полшаш каена. 'I beg you, let's help our sister, please.' (There are three markers here). Поро лий йолташем, имньым кычкен шогалте-ян. 'Be so kind, my friend, harness the horse, please.' (There are two markers here).

In the Russian language: Будь добр, Николай, заходи-ка к нам и расскажи, пожалуйста, правду (there are three markers at once). 'Nikolay, will you come in, please, and tell us the truth, if you please';

In the French language: Je t'en supplie, ne dis pas, s'il te plaît, je te prie (there are three politeness markers).

Courtesy markers used together provide a vivid effect of politeness which is used by the speaker to implement his speech strategy in speech interaction.

Interrogative constructions of various configurations are distinguished as a means to soften the utterance along with these courtesy markers in the Chuvash, Mari, Russian, and French languages. The most frequent are interrogative-negative constructions represented by the verb in the future tense in the negative form in combination with a particle.

For example, in the Chuvash language: Tури касса утмӑр-ши? 'Would you like to come to Turikas?' Петр Константинович, тата с̧акна каласа памӑр-ши? 'Peter Konstantinovich, could you tell me more about this?'

In the Mari language: Чодыраш каймыда огеш шу мо? 'Would you like to go to the forest?' Пуэн кертыда мо тиде книгам йолташемлан? 'Will you pass the book to my friend, please?'

In the Russian language: Не передадите ли Вы это письмо? 'Will you give me the letter, please.' Вы не согласились бы зайти ко мне? (particles ли, бы) 'Don't you mind to come to us?'

The following construction is the functional analogue in the French languages: Ne pouvez-vous pas + inf. + s'il vous plaît, for example: Ne pouvez-vous pas me donner votre livre, s'il vous plaît?

A more polite equivalent of these requisition statements is a request hidden by an interrogative-negative construction that has a verb form in the future tense with the meaning of modality. For example:

In the Chuvash language: Пулӑшаймӑр-ши? 'Could you help me?' Ирина кӗрӗкне касаймӑр-ши паян? 'Could you cut Irina's fur coat today?'

In the Mari language: Полшен огыда керт мо мыланем? 'Could you help me?'

In the Russian language: Не можете ли Вы дать мне несколько рублей взаймы? 'Will you lend me some money, if you please?'Не могли бы вы оставить всё и вырваться к родителям? 'Could you put off everything and visit your parents?'

In the French language: Vous ne pouvez pas me dire? Vous ne pourriez pas monter le chauttage.

The above statements in the Chuvash, Mari, Russian and French languages illustrate the speaker's politeness. They also show that the combination of a question-negative structure with a future tense form establishes the required level of caution and insecurity, adds politeness to the expressions. It should be noted that this uncertainty is reduced by varying the forms of indicative and conjunctive in speech interaction. Thus these formulas allow us to reflect, to some extent, the unobtrusiveness, delicacy and politeness of the speaker. Highlighted interrogative constructions are the most common in these languages and have secured the status of polite formulas.

It is important to mention interrogative constructs with the verbs in the imperative form with affixes: 
-сам/-сем, -самӑр/-семӗр in the Chuvash language. For example:

In the Chuvash language: Чӗлӗм туртма та пулсан ирӗк парсамӑрччӗ? 'May I smoke, please?' This construct is used to mark polite permission with a hint of pleading.

Similar constructions are found in the speech of Russian and French. They are presented in the form of grammatical constructions with the modal verb мочь 'may' in Russian and pouvoir in French:

In the Russian language: Могу я вставить словечко? 'May I have my word?'

In the French language: Puis-je demander de signer ici, chère Madame?

Communicants use etiquette expressions in the interrogative form quite often in speech interaction. The pattern 'modal verb + performative verb' is used to form the following synonymic row:

Rus. могу я попросить (пригласить, посоветовать) + инфринитив? 'May I ask (invite, advise) you + to infinitive?'

Fr. Puis-je vous demander (inviter, conseillar + inf); Pourrais-je vous demander de + inf.

Rus. Могу я попросить у Вас чашку чая? 'May I ask you a cup of tea?' Могу я пригласить Вас на танец? 'May I invite you for dancing?'

Fr. Puis-je demander de me donner votre livre.

The infinitive construction is a functional analogue of these polite expressions in the Chuvash language: Сирӗнтен ыйтма юрать-и? 'May I ask you?', and in the Mari language: Каяш лиеш? 'Can I go?'

The use of the above formulas in the native speakers' discourse contributes to polite speech interaction, strengthening the speaker's communicative intention. So it reveals the tactical and strategic nature of the impact on the listener.

Declarative sentences play a special role in courtesy principles explication. Indicative forms of the second person are used as polite requests in the languages under consideration according to the study of dialogical texts, for example:

Chuv. Эсӗ килте юлатӑн, amme. 'Will you stay at home, dad.'

Mar. Тый мыланем муралтет. 'Will you sing for me'; Эрәым, тый монгышто кодат. 'Will you stay at home, dad.

Rus. Ты меня пустишь? 'Will you let me in?'

Fr. Tu lis, toi.

These statements have a present-future perspective and they are quite often found in the communicants' speech of the considered linguistic cultures.

Politeness can be conveyed through narrative constructions with the verb in the subjunctive mood in some communicative situations. For example:

In the Chuvash language: Юлташ тесе пӗр сӗнў парӑттӑм сана. 'I would give you advice because you are my friend'.

In the Mari language: Каена ыле зын чодыраш. 'We would go to the forest'. Лудына ыле книгам. 'You'd better read the book'.

In the Russian language: Пошли бы в поселковый совет. 'You'd better go to the administration'.

The functional synonym in French is Imparfait, for example:

Fr. Berthe si tu chantais pour la petite.

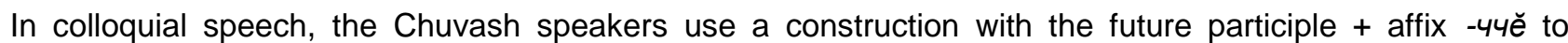
express polite statements, for example:

Chuv. Эпӗ сана сёнў парасшӑнччӗ. 'I would like to give you advice'.

This construction is used to mark polite communication when the speaker intentionally emphasizes his attitude to the addressee, revealing his interest in communicative cooperation.

Narrative constructions with performative verbs to ask, to advise in the first person singular, in future tense are of particular interest in the Chuvash, Mari, Russian and French languages. They are used by native 
speakers as polite statements in speech. For example, Chuv. Хăвăртрах сипленме ыйтап. 'I would also like to ask you to recover faster'; Mar. Мый йодам толаш тендам ондакырак. 'I ask you to come earlier'; Rus. Я прошу вас вычеркнуть эту сцену. 'I want you to drop this scene off'; Fr. Je te demanderai seulement de me donner une chance.

It should be mentioned that these performative verbs are also used in the subjunctive mood giving expressions a certain shade of politeness, for example: Chuv. Эпӗ сире каласа пама ыйтӑтmăм. 'I would ask you to tell us about ...'; Mar. Мый йодам ыле тендам книгам лудаш. 'I would ask you to read the book'; Russian Я бы попросил не мешать. 'I would ask you not to disturb'. The functional analogue of such statements is a narrative construction with a verb Conditionnel present in French. For example, Je vous demanderais d'emporter une affiche.

Modal constructions are used in speech interaction. The pattern I would like (can) + performative verb (to ask, to advice, to warn), which is necessary for the polite tone of communication. For example:

In the Mari language: Мый кертам пуэн тыланда канашым пашаш пураш. 'I can give you advice to get a job'.

In the Russian language: Но посоветовать могу. 'I can advise you'; Я вот что предложить хочу. 'There is something l'd like to propose'.

In the French language: Je veux, en premier vous demander. Je peux demander une chambre au lycée.

The construction with the future participation is a functional synonym in the Chuvash language, for example: Пӑртак кётме ыйтасшӑн сире. 'I want to ask you to wait a bit'.

Observations of the verbal behavior of communicants who are representatives of these linguistic cultures show that modal constructions serving to express politeness dominate the speech of French.

\section{CONCLUSIONS}

The study of the courtesy category in different structural languages has showed that it is represented in all the languages which we have analyzed, namely in Chuvash, Mari, Russian and French. The courtesy markers under consideration form a whole microsystem of polite expressions in these languages. They are widely used by communicants of different sexes and ages in order to establish friendly relations in the process of speech interaction. However, the number of politeness markers in Chuvash, Mari, Russian and French do not coincide. Comparison of courtesy markers in the speech of native speakers of the analyzed languages allowed revealing the frequency of word-forming means of politeness expression. Thus, the verbal affix -сам/-сем, -самӑp/-семӗр are used in the Chuvash language. Imperative in combination with particles and interjections are used in the Mari and Russian languages. French is characterized by the frequent use of the subjunctive mood. Lexical means of courtesy explication (special polite 'please', 'I ask you') are actively used in all four languages.

Interrogative and narrative constructions are the dominant politeness markers in the languages in terms of syntax. The use of interrogative constructions and their variants dominates in the French language. Representatives of the Chuvash, Mari and Russian linguistic cultures more often use narrative constructions. The choice of various means of courtesy principles explication is determined by many factors. First of all, the specific type of speech interaction, tactics and communication strategies of communicants should be mentioned.

\section{REFERENCE LIST}

1. Andreev, I. A. (1985). The Chuvash-Russian Dictionary.

2. Ashmarin, N. I. (1994-2000). The Dictionary of the Chuvash language.

3. Gak, V. G. (2003). New French-Russian Dictionary.

4. Le Grand Robert. (1990). De la langue Fransaise.

5. Leech, G. (2014). The pragmatics of politeness.

6. Ozhegov, S. I., Shvedova, N. Yu. (1996). The Explanatory Dictionary of the Russian Language.

7. The Dictionary of the Mari Language (1990-2005). 
8. Ushakov, D. N. (1935). The Explanatory Dictionary of the Russian Language.

9. Formanovskaya, N. I. (1989). Speech etiquette and communication.

10. Yakovlev, I. Ya. (1985). Letters. 